\section{A contemporary view of glyphosate}

The idea of this issue dedicated to the herbicide glyphosate (Figure 1) was born in a meeting on 2014 in Cambridge, at which Brian Baxter, an East Anglian farmer and some others participated. The starting point was the perplexity of the farmer, who is aware that modern industrial farming practices grow for quantity, not quality. Hence, as Thomas concluded, "the nation [Britain], as a whole, is overfed but malnourished" [1]. The farmer is also aware that the increasing amount of chemicals deliberately added to the soil during the past few decades has somehow rendered the soil less capable of carrying out its rôles. A particular problem has been created by glyphosate, which has become the most widely used herbicide in the world. Just as a monoculture is a very fragile ecosystem, as was discovered to the great detriment of the coffee industry in Ceylon in the 1880s, the application of a single chemical in ever-increasing quantities is also likely to lead to ecological fragilisation, if one may borrow that convenient word from the French. Although glyphosate was initially seen as attractive because of its low toxicity to animals, its collateral toxicity to bacteria has led to unanticipated problems: decimation of the microbiota of the rhizosphere, which adversely affects even plants genetically modified to resist the direct herbicidal action; and decimation of the microbiota of the gastrointestinal tract (GIT) of animals, including humans. "Decimation" is really the wrong word; it is known that the GIT has an extremely complex microbial population, constituted from very many different strains, and when it is subjected to a broad-spectrum antibiotic like glyphosate the balance of strains is severely disrupted - some may disappear completely, while hitherto minor members of the community expand their populations to dominate. Although it is not at first sight obvious why glyphosate should act in such a fashion, it appears to favour pathogenic, or potentially pathogenic strains rather than benign ones (possibly because the former are generally more robust than the latter).

These undesirable aspects of the deployment of glyphosate would doubtless have remained manageable were its use to have remained confined to a small niche. Yet particularly since the expiry of its patent protection, production has greatly expanded (it was about $720 \mathrm{kt}$ in 2012, and is expected to reach 1.35 Mt in 2017) throughout the world. China alone produces more than $40 \%$ of global supply. One consequence is that glyphosate has become ubiquitous in our environment: in soil, in water and even in ourselves. Even if a farmer decides to completely eschew its use, he can scarcely isolate himself from it because of this ubiquity. It is of great concern that glyphosate is such an effective metal chelating agent (its first patent was for that purpose [2]). Hence, its ever-increasing use has exacerbated the increasing tendency towards trace element deficiency in our diets [1]. Furthermore the weeds, the primary target of glyphosate, are developing resistance and, therefore, to achieve the same herbicidal effect, ever-increasing quantities of glyphosate need to be applied, exacerbating the development of resistance and the environmental ubiquity. In the light of such facts, the not untypical opinion that "glyphosate is essential for present and future world food production" [3] begins to sound rather absurd.

Unfortunately such logical leaps of faith (the quotation summarizes a review of glyphosate-resistant weeds) seem to be quite common. Another wildly optimistic survey of farmers in Germany concludes that "glyphosate offers large benefits to farmers" [4]. A dispassionate reader of the facts presented in the article is unlikely to come to that conclusion, even without taking into account other known facts (such as the development of resistance) that have been omitted. To the outside onlooker who, like the farmer, may have a great practical interest in the matter, the overall situation is highly unsatisfactory, not least because of the difficulty in sifting through the vast mass of data and opinion now available. A great deal of information appears in the "grey literature", nowadays dominated by more-or-less ephemeral websites. Mysterious organizations such as the "Glyphosate Task Force" (GTF) occasionally post articles on the web. Protagonists (the manufacturers but, also, and worryingly — we shall return to this later - governments and official regulatory agencies) and antagonists (organic farmers and "activists") alike seem to be largely misinformed; at least that is the impression from their web postings; it may be due to an excessive desire to promote their viewpoint, leading to bias, possibly unconsciously. There is a dearth of serious academic literature taking an objective, disinterested view of the matter in which the whole truth is presented, at least to the level of current knowledge, with clarity regarding its limits.

In our present era, in which Weir's "vulgar sophism" holds sway, ${ }^{1}$ it is not too surprising that manufacturers seek to promote their interests, namely maximizing turnover.

\footnotetext{
1 "The elevation of society was lost sight of in a feverish desire to acquire money. Beneficial undertakings had been proved profitable; and it was now assumed that a business, so long as it was profitable, did not require to be proved beneficial. The sophism suited vulgar inclinations, and its authority became a principal force in the social dynamics of modern Europe" [5].
} 


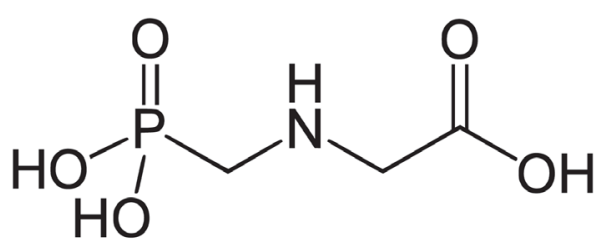

Figure 1. Glyphosate. Note that in this form the substance is only moderately soluble in water $\left(11.6 \mathrm{~g} / \mathrm{L}\right.$ at $25^{\circ} \mathrm{C}$ according to the IARC “Glyphosate Monograph”).

What is particularly reprehensible is the extent to which they seek, by dishonest means, above all by lobbying politicians, to go beyond simple statements of what they believe to be the advantages of their products. Lobbying has truly become a scourge of our time. ${ }^{2}$ It has even been uncovered in Switzerland (albeit at a smaller and more discreet scale than elsewhere), a country long believed to be largely free of it. Grave doubts have therefore grown up regarding whether governments and their agencies indeed act "für das Wohl des Volkes". This has become particularly prominent in the USA and the European Union. The precautionary principle is actually enshrined in the EU treaties [6]. The problem with agricultural technology is that it is deployed on a very large scale as far as the environment is concerned. Perhaps because so few people are nowadays employed in agriculture (typically $1-$ $2 \%$ of the working population in developed economies) this is not generally perceived. When one thinks of the enormous hurdles faced by a manufacturer who seeks to introduce a new drug, which may only ever be prescribed to a tiny fraction of the population, or a new bactericidal cleaning agent, which will be applied under strictly confined conditions, comparison with the general laxness that accompanies the authorization of agricultural chemicals and genetically modified organisms is incongruous. Risk is the product of exposure and hazard. It is well known that government officials typically have received an education based on the classics rather than mathematics or science and, in consequence, face a lifelong disadvantage when it comes to appraising numerical matters. Provided its production remains on a minuscule scale, even a highly potent toxin may not require particularly restrictive regulation. On the other hand, a mildly toxic substance - such as glyphosate - is readily authorized because, it seems, only the hazard is scrutinized by the regulatory authorities, without consideration of the likely exposure of the population. A typical case is presented by the reaction to the International Agency for Research on Cancer (IARC, a branch of the World Health Organization, WHO) "Glyphosate Monograph", in which, following an exhaustive analysis of the literature, it was concluded that glyphosate is "probably carcinogenic". On 30 July 2015, the day after publication of the IARC monograph, the Swiss Federal Office for Agriculture ${ }^{3}$ released the the depreciatory statement "Glyphosat wurde in den letzten Jahren mehrmals durch verschiedene Behörden, nationale und internationale Expertengremien wie EFSA und JMPR überprüft und als nicht krebserregend bewertet. Dabei wurden hunderte Studien berücksichtigt. Auch im Rahmen der neusten, erst kürzlich durchgeführten Ueberprüfung von Glyphosat durch die EU wurden basierend auf der Neubewertung von mehr als 1000 Studien keine Hinweise auf eine krebserregende Wirkung gefunden. Der IARC standen für den Entscheid Glyphosat als karzinogen einzustufen keine neuen, international anerkannten Studien zur Verfügung". "The hazard enshrined in "probably carcinogenic" might be relatively low but given the present ubiquity of glyphosate - recently it has been shown that even the feed for laboratory rats is contaminated with glyphosate to such a degree that the difference between diets to which additional glyphosate is deliberately added and the "glyphosate-free" controls is diminished, resulting in a false impression of safety ${ }^{5}$ - the risk appears to be considerable. The most favourable light in which a statement like that of the BLW can be seen is one of resignation: even the government realizes that the situation with glyphosate has got out of control, and the best that can be done is to dampen anything that might alarm the public. In other countries the situation is typically much worse. ${ }^{6}$ One recalls the sober assessment of the dangers of organophosphate pesticides in the Zuckerman report [7], which was followed a few decades later by the introduction of compulsory sheep dipping in organophosphate pesticides without the requisite precautions, resulting in widespread illness among sheep farmers, only very belatedly acknowledged [8].

Possibly governments have a tendency to receive bad scientific advice. After all, no real devotee of science would prefer to leave his laboratory or study in order to proffer advice to his or her government as a profession,

\footnotetext{
2 Nowadays, even some scientists lobby European Union officials, maintaining apartments in Brussels for the purpose, in order to promote their research proposals and increase their chances of being funded by the EU research and technical development programmes.

3 Bundesamt für Landwirtschaft BLW (Fachbereich Nachhaltiger Pflanzenschutz).

4 Position BLW zur Neueinstufung von Glyphosat als krebserregend durch die IARC.

5 See the review by Séralini in this issue.

6 At least in Switzerland the practice of applying glyphosate just before crop harvest is (still) forbidden.
} 
and the very few examples of high-minded individuals doing so-Sir Henry Tizard and Zuckerman himself come to mind - rather suggest themselves as exceptions proving the rule. Added to that is the problem, already mentioned, that governments the world over have fallen too much under the influence of special interest groups pressing their desires through lobbying. The pesticides and the increasingly international genetically modified organisms (GMO) businesses are prominent examples of such groups. There is, of course, no shortage of activists opposing pesticides and GMOs, who also vociferously press their claims, but presumably their voices receive a less favourable hearing because their activities do not generate tax revenue for the government.

Given this background, it seemed very timely to invite leading scientists involved with assessing glyphosate to contribute papers that would be gathered together in a single issue of the journal. The "invitation" was actually a widely disseminated general announcement. An unavoidable feature of such a procedure is that one can neither control nor predict what papers will arrive, nor when; indeed they are still arriving and the topic remains open for contributions. The overwhelming majority of submissions dealt with cancer, possibly inspired by the recent publication of the IARC monograph. This may not represent balanced coverage. A great many substances are potentially carcinogenic and, practically, no more avoidable than oxygen. The ultimate outcome surely depends on the multiplicity of other factors operating in parallel, although in a few exceptional cases, such as the unfortunate inhabitants of the three Turkish villages Karain, Tuzköy and Sarihidir built on and from erionite [9], there may be no escape.

Revealingly, no papers overtly defending glyphosate were received, let alone accepted for publication. Some may point to what has been called Toyber's dictum, "absence of evidence is not evidence of absence" [10] in seeking to explain this phenomenon, although elementary probability theory would suggest the opposite. So why is defence absent? One possible answer is that the defenders prefer to post their opinions on the web. For example, Monsanto, the chemical company that originally patented and developed glyphosate as a herbicide, have posted an 80-page report entitled "The agronomic benefits of glyphosate in Europe. Review of the benefits of glyphosate market use." It is, of course, comfortable to follow that path, which obviates the scrutiny of referees prior to publication. Three days after a summary of the IARC monograph was published in The Lancet Oncology, Monsanto issued a press release (St Louis, 23 March
2015) denouncing the IARC conclusions with "we are outraged with this assessment" (astonishingly, the position statement of the $\mathrm{BLW}^{3,4}$ is remarkably similar to this press release). Does not the company have the resources to write a proper critique fit to be subjected to peer review? No such critique appears to have been published, neither in The Lancet nor anywhere else to my knowledge.

The main argument in favour of glyphosate is that by eliminating weeds it helps us to grow more food. Along with insecticides and artificial fertilizers it is, therefore, part of the "green revolution" frequently associated with the name of Borlaug. To put this so-called "revolution" in perspective, it is more historically accurate to view it simply as the culmination of a very long history of the development of ways to overcome all kinds of pests (including viruses, fungi, bacteria, insects and weeds). ${ }^{7}$ The premisses of this development, particularly in its latter stages, may, however, be wrong. Biological control may be far more effective in the long term $[12,13]$. So why has this not been taken to heart? One reason could simply be the preponderant tendency of man to favour short-term solutions. A deeper reason could be the fundamentally predatory nature of man, which Spengler has pointed out [14], indicating that it leads to an overweening desire to dominate nature and that technology is the means to fulfil that desire. According to this idea, it is obvious that man will favour a man-made solution over biological control, even though the latter does demand the exercise of considerable human ingenuity. Large, an engineer, pooh-poohs Howard's picturesque notion of pests acting as "nature's censors", indicating where certain crops should not be grown [11]. Yet nature is wily: resistance to antibiotics emerges (and is nowadays perceived as one of the greatest threats to medicine), not only among bacteria but also among weeds [3]. The lessons of the coffee crisis in Ceylon have not been learnt. Antibiotics indeed diminish the death rate, perhaps nowhere more dramatically as in those parts of the world which, traditionally, have poor nutrition, including large parts of Africa [15]. The ability to force food productionat least in quantity, if not necessarily in nutritional quality per unit mass - acted synergistically with the medical advances to engender a vast increase in population. This has driven the world to a very precarious state, because all those extra people also need energy and other resources [16]. Even the protagonists of pesticides such as Roundup presumably realize this, which is why the justification of "preventing mass starvation" is only a murmur in the background.

Besides, in our era of the "vulgar sophism", ${ }^{1}$ being beneficial is anyway in the background. All that counts is

\footnotetext{
7 See ref. 11 for a fascinating account of this development.
} 
that a business should be profitable, a goal achievable with a combination of demand and the ability to satisfy it with an attractive margin. If farmers are gullible enough to believe that glyphosate will help them, is it wrong to supply it to them? As for the safety, this is nowadays handled impersonally by a web of regulatory authorities, for which the Alkali Inspectorate (created in 1864) was the pioneer. ${ }^{8}$ The first inspector, Robert Angus Smith, appears to have been an exemplary personality. Many of his successors in the multitude of regulatory agencies that nowadays exist around the world have turned out to be epigones. ${ }^{9}$ The "triple helix" of government, industry and universities [19] has on the whole tended to rather onesidedly support the "vulgar sophism". ${ }^{1}$ Thanks to recently released documents, the US Environmental Protection Agency have likewise been cast in a rather unfavourable light regarding the authorization of glyphosate. ${ }^{10}$

This dismal track record has undermined confidence in the regulatory authorities, which were originally set up to protect the public, as a counterbalance to the great weight of the capital concentrated in a joint-stock company, which nevertheless as a juridical personality had only limited liability, in contrast to the unlimited liability of a natural personality. This great weight has also been used to apply pressure to the regulatory authorities. In many cases it is not necessary for this pressure to be very overt; it seems to have sufficed to simply provide misleading laboratory evidence. ${ }^{\mathbf{1 0}}$ At first sight, it would appear that such systematic attempts to distort the evidence regarding the toxicity of glyphosate should be easily identified by the regulatory authority. In practice, some of the individual members of the committee tasked with reaching a decision regarding authorization may feel they lack the solid statistical background needed to challenge the distortion; others may indeed have had, individually, pressure applied by the industry making the application for regulatory approval. Obviously, such members should abstain from voting, or their votes should be disregarded, but usually the members will never admit to these deficiencies, so the matter goes through. Even worse are the conflicting dual rôles of some members, whose discretion thereat amounts to concealment. Indeed the divergence between evidence and decisions has become so blatant and widespread it could even form the topic of a scientific analysis [20].
Of at least comparable concern is the corruption of the disinterested and impartial process of scientific publication. ${ }^{5}$ Publishers themselves are evidently now followers of Weir's "vulgar sophism". ${ }^{1}$ To this may be added the unsavoury rôle of the Royal Society of London in the furore surrounding the paper of Ewen and Pusztai on the deleterious effects of consuming genetically modified potatoes [21].

Continuing with our attempt to identify the advantages of glyphosate, we may again look at the papers, already mentioned, of Powles [3] and Steinmann et al. [4] The former concludes that "Glyphosate is essential for present and future world food production, and action to secure its sustainability for future generations is a global imperative." This paper was published one year after the symposium "Mineral Nutrition and Disease Problems in Modern Agriculture: Threats to Sustainability?", the proceedings of which were later published in the European Journal of Agronomy [22]. As for Steinmann et al., they completely ignore weed resistance in their "uses and benefits" paper.

So much for the benefits of glyphosate. As for the negative aspects, apart from the carcinogenicity, which is exhaustively handled by other papers in this issue, we have the hazards of:

- endocrine and neurological disruption; ${ }^{5}$

- effects on the cytochromes P450 [23];

- effects on the gastrointestinal tract (one of the few papers on this topic is that of Shehata et al. [24]; the study of the gut microbiota is however advancing far and fast now [25] and it is to be hoped that studies of the effect of glyphosate on the human gut microbiota will be carried out in the nearest future;

effects on soil ecosystem diversity-hitherto not studied but their occurrence seems obvious;

trace element chelation in the soil [2], leading to depletion of essential elements.

It may hardly be necessary to mention that the increase of glyphosate use is strongly correlated with the spread of crop varieties genetically modified to resist glyphosate. The sustainability of this combination is in doubt, not only because of the growth of weed resistance but also because of the deleterious effects of glyphosate on the rhizosphere microbiota of the "resistant" plants [26-28].

8 Just how different was the attitude in the days before the "vulgar sophism"1 held sway can be seen from Isambard Kingdom Brunel's opposition to the appointment of government inspectors of railways in 1841: "Railway engineers understood very well how to look after the public safety, and putting a person over them must shackle them. They had not only more ability to find out what was necessary than any inspecting officer could have, but they had a greater desire to do it" [17].

9 An instructive exanple is provided by the history of tetraethyl lead. Almost immediately after its large-scale production began (in the USA), workers in the plants were found to become psychotic [18]. Despite this initial evidence of toxicity, after a brief production moratorium and an investigation led by the Surgeon General, the compound was pronounced to be safe for general use.

10 See the review by Samsel \& Seneff in this issue. 
The ubiquity of glyphosate in our environment inspired an important study of the physiological effects of administering glyphosate over long periods at levels not exceeding those permitted in drinking water. The results, on laboratory rats, revealed extensive and alarming gene disturbances and organ damage [29]. If these results are corroborated in humans, the extreme inadequacy of the current approach of the regulatory authorities (measuring the lowest acute dose required to cause an observable physiological effect) will be revealed, apart from all their other problems as discussed above.

If farmers and the general public can no longer rely on the official regulatory agencies to look after their interests, there is a greater imperative than ever for every individual to educate himself or herself sufficiently to be able to appraise a matter of this nature to a degree adequate to enable a reasonable decision of what to do to be taken. ${ }^{11}$

One final point needs to be made. In his admirable review of the original laboratory records of some of the early glyphosate testing, Cuhra ${ }^{12}$ found that one of the key (typewritten) laboratory reports bore a later handwritten annotation. Physical records, which usually means on paper, cannot be tampered with without leaving some trace, but this does not apply to electronic records, which can often be manipulated without leaving any trace [31]. Now that "laboratory information systems", which usually means all-electronic records, are becoming more and more widespread, this safeguard is disappearing. Of course the systems are designed to make it difficult to alter records retrospectively, but as any IT specialist knows, no system can be completely tamper-proof. Unless there is a strong change in current attitudes towards the sanctity of original data, this development bodes ill for our future ability to effectively scrutinize the original evidence on which regulatory decisions are supposedly made.

\section{J.J. RAMSDEN}

\section{References}

1. D.E. Thomas, The mineral depletion of foods available to us as a nation (1940-2002). Nutrition Health 19 (2007) 21-55.

2. A.D.F. Toy, P. Forest and E.H. Uhing, Aminomethylenephosphinic acids, salts thereof, and process for their production. US Patent No 3,160,632 (1964).

3. S.B. Powles, Evolved glyphosate-resistant weeds around the world: lessons to be learnt. Pest Management Sci. 64 (2008) 360-365.

4. H.H. Steinmann, M. Dickeduisberg and L. Theuvsen, Uses and benefits of glyphosate in German arable farming. Crop Protection 42 (2012) 164-169.

5. A. Weir, The Historical Basis of Modern Europe, p. 394. London: Swan, Sonnenschein, Lowry (1886).

6. Article 191 of the Treaty on the Functioning of the European Union (Lisbon Treaty). See also Article 174 of the Maastricht Treaty.

7. S. Zuckerman, Toxic Chemicals in Agriculture (Report to the Minister of Agriculture and Fisheries of the Working Party on Precautionary Measures against Toxic Chemicals used in Agriculture). 1951.

8. Health and Safety Executive (UK), Field Operations Division. Sheep Dip Survey 1990. Internal Report (May 1991).

9. C.J. van Oss and R.F. Giese, Properties of two species of deadly nano-needles. Nanotechnol. Perceptions 5 (2009) 147-150.

10. D.G. Altman and J.M. Bland, Absence of evidence is not evidence of absence. BMJ311 (1995) 485.

11. E.C. Large, The Advance of the Fungi. London: Jonathan Cape (1940).

12. A. Howard, An Agricultural Testament. London: Oxford University Press (1940).

13. R. van den Bosch and P.S. Messenger, Biological Control. New York: Intext (1973).

14. O. Spengler, Der Mensch und die Technik. Munich: C.H. Beck (1931).

15. A. Schweitzer, On the Edge of the Primeval Forest. London: Adam \& Charles Black (1922).

16. J.R. Schramski, D.K. Gattiea and J.H. Brown, Human domination of the biosphere: Rapid discharge of the earthspace battery foretells the future of humankind. Proc. Natl Acad. Sci. USA 112 (2015) 9511-9517.

17. L.T.C. Rolt, Isambard Kingdom Brunel, pp. 217-218. London: Longmans, Green \& Co. (1957).

18. H.I. Needleman, The removal of lead from gasoline: historical and personal reflections. Environmental Res. A 84 (2000) 20-35.

19. H. Etzkowitz and L. Leydesdorff, The dynamics of innovation: from National Systems and "Mode 2" to a Triple Helix of university-industry-government relations. Research Policy 29 (2000) 109-123.

20. M. Antoniou, M.E.M. Habib, C.V. Howard, R.C. Jennings, C. Leifert, R.O. Nodari, C.J. Robinson and J. Fagan, Teratogenic effects of glyphosate-based herbicides: divergence of regulatory decisions from scientific evidence. J. Environ. Anal. Toxicol. (2012) S4:006.

21. S.W. Ewen and A. Pusztai, Effect of diets containing genetically modified potatoes expressing Galanthus nivalis lectin on rat small intestine. The Lancet 354 (1999) 1353-1354.

22. T. Yamada, R.J. Kremer, P.R. de Camargo e Castro and B.W. Wood, Glyphosate interactions with physiology, nutrition, and diseases of plants: Threat to agricultural sustainability? Eur. J. Agronomy 31 (2009) 111-113.

\footnotetext{
${ }^{11}$ Cf. "Aufklärung ist der Ausgang der Menschen aus seiner selbstverschuldeten Unmündigkeit. Unmündigkeit ist das Unvermögen, sich seines Verstandes ohne Leitung anderer zu bedienen. . Faulheit und Feigheit sind die Ursachen, warum ein so grosser Teil der Menschen ... gerne zeitlebens unmündig bleiben und warum es anderen so leicht wird, sich zu deren Vormündern aufzuwerfen" [30].

12 This issue.
} 
23. A. Samsel and S. Seneff, Glyphosate's suppression of cytochrome $\mathrm{P} 450$ enzymes and amino acid biosynthesis by the gut microbiome: pathways to modern diseases. Entropy 15(2013) 1416-1463.

24. A.A. Shehata, W. Schrödl, A.A. Aldin, H.M. Hafez and M. Krüger, The effect of glyphosate on potential pathogens and beneficial members of poultry microbiota in vitro. Current Microbiol. 66 (2013) 350-358.

25. T. Korem et al., Growth dynamics of gut microbiota in health and disease inferred from single metagenomic samples. Science 349 (2015) 1101-1106.

26. R.J. Kremer and N.E. Means, Glyphosate and glyphosateresistant crop interactions with rhizosphere microorganisms. Eur. J. Agronomy 31 (2009) 153-161.

27. T. Tesfamariam, S. Bott, I. Cakmak, V. Römheld and G. Neumann, Glyphosate in the rhizosphere-role of waiting times and different glyphosate binding forms in soils and phytotoxicity to non-target plants. Eur. J. Agronomy 31 (2009) 126-131.

28. L.H.S. Zobiole, R.J. Kremer, R.S. Oliveira and J. Constantin, Glyphosate affects chlorophyll, nodulation and nutrient accumulation of "second generation" glyphosate-resistant soybean (Glycine max L.) Pesticide Biochem. Physiol. 99 (2011) 53-60.

29. R. Mesnage, M. Arno, M. Costanzo, M. Malatesta, G.-E. Seralini and M. Antoniou. Transcriptome profile analysis reflects rat liver and kidney damage following chronic ultralow-dose Roundup exposure. Environmental Health 14 (2015) 70 (14 pp.).

30. I. Kant, Beantwortung der Frage: Was ist Aufklärung? Berlinische Monatsschrift 4 (1784) 481-494.

31. W. Wirth, The end of the scientific manuscript? J. Biol. Phys. Chem. 2 (2002) 67-71. 